\title{
Epithet and Eponym
}

\section{KEMP MALONE}

$T$

HE LATE Robert L. RAMSAy in a recent paper ${ }^{1}$ contends that King Scyld of the Danes "was surely an eponym if there ever was one." More precisely, he believes that the king's name was made, by back formation, from the dynastic name Scyldingas, and that the dynasty got its name from the shields with which its members were armed. As he puts the matter in an earlier study, "the Saxons got their ancestral name from their favorite weapon, the seax or knife, the Scyldings from their shields, ..."2 From this statement, be it added, one might readily infer that Ramsay looked upon Scyldingas as a tribal rather than as a dynastic name, supporting himself, presumably, upon the tribal sense 'Danes' that Scyldingas often if not usually has in the English poem Beowulf. But in his later paper he accepts as correct the view that "the Danes are repeatedly called Scyldings in the poem by extension of the name as applied to the royal family" (p. 274), and his discussion makes it clear that the distinction between dynastic and tribal was of no moment to him. He evidently (and rightly) thought it to have no bearing on the etymological problem with which he was concerned. This problem may be summed up as follows. Was the proper name Scyld made, by back formation, from the dynastic or tribal name Scyldingas? If so, then King Scyld is an eponym. Or is Scyldingas a patronymic in origin, derived from the proper name $S c y l d$ ? If so, then King Scyld is not an eponym. If the king is an eponym we have an explanation of his name but need to explain the name Scyldingas. If he is not an eponym we have an explanation of Scyldingas but need to explain the use of the common noun scyld 'shield' as a royal name. In my paper of 1953 (to which Ramsay took exception), I chose the second alternative and tried to explain how a king might come to have such a name as Scyld. ${ }^{3}$ Ramsay however chose the first alternative and accordingly tried to explain how a dynasty or tribe might come to have such a name as Scyldingas. 
As we have seen, Ramsay believed that the Scyldings got their name from their shields. In other words, he took the etymological meaning of Scylding to be 'shield man, son of the shield' or the like. Now the Danes undoubtedly bore shields when they went into battle. But so did their neighbors. There is nothing peculiarly or distinctively Danish about a shield, and it is hard to see what made Scylding a suitable name by which a Danish prince or tribesman could be distinguished from a man who belonged to some other tribe. To put the point differently, it is hard to see how a word with the etymological meaning 'man of the shield' could come to mean 'Dane.' Semantically considered, this way of explaining the name of the Danish royal house lacks plausibility.

In support of his etymology Ramsay brought forward two wordgroups: (1) dynastic or tribal names parallel to Scylding in formation; and (2) names unlike Scylding in form but thought to be parallel in sense. The names of the two groups have in common one feature: the base of each name denotes, or may be taken to denote, some offensive or defensive weapon. Under (1) come three names: Ascingas, Brondingas, and Helmingas. Under (2), four names: Engle, Francan, Longbeardan, and Seaxe or Seaxan. I will take up these names in turn.

Escingas 'sons of the ashen spear' (to use Ramsay's translation) must be dismissed from consideration at once. In Bede's History we are told (ii.5) that Oisc was son of Hengist and that after him the kings of Kent were called Oiscings. In the Old English Annals the name Oisc does not appear, Esc being used instead (whence Ramsay's Ascings), but Oisc has the authority of Bede and the genealogies behind it and is generally reckoned the right form." Ramsay interprets Brondingas as 'sons of the sword' and Helmingas as 'sons of the helmet,' but this interpretation hardly yields distinctive tribal or dynastic names, since all Germanic warriors fought with swords and wore helmets in battle. In the paper of 1953 referred to above I took these names to mean 'offspring of Brond' and 'offspring of Helm' respectively; in other words, I took them for patronymics, based on the well-known royal names Brond and Helm. A dynasty that traced its ancestry back to Brond or Helm would have Brondingas or Helmingas for name, as the case might be, and this explanation of the names makes no difficulties. Engle, the old tribal name from which the adj. English is de- 
rived, goes with Ongel (modern Angeln), the name of the district in Sleswick where the English had their oldest known seats. ${ }^{5}$ The tribal name is first recorded in the Germania of the Roman historian Tacitus, where it has the latinized form Anglii. Both the tribal and the district name show a base ang extended by an $l$-suffix. The meaning and connections of this ang are uncertain, but Ramsay may well be right in connecting it with Old English anga, Icelandic angi, and Old German ango. These cognates all denote a kind of weapon; namely, the sting with which bees and hornets are equipped. The words may also denote a man-made weapon, the goad; but this, of course, is not a weapon of war and Ramsay was not thinking of goads, much less of stings, when he brought the name of the English into the picture. Again, our cognates may denote the stinging part (i.e. the point) of something. Thus, anga means 'point (of an arrow)' in the 23rd riddle of the Exeter Book. The riddler has an arrow in mind but avoids earh 'arrow' because this word would at once reveal the fact that bow is the solution of the riddle. In the Franconian dialect of Old German, ango had the sense 'barbed spear' (at first, no doubt, it denoted the barb only), but this meaning is late and cannot properly be brought to bear when we deal with the etymology of the very ancient tribal name Anglii. It is safe to say that the Anglian tribesmen were not so called because of any distinctive weapon with which they were armed in warfare. In my opinion the base ang and the words discussed above are connected with Ing, the name of an old fertility deity worshipped by the English in heathen times. The name Ing in all likelihood means 'phallus' and the English may owe their name to their old religion.

Francan 'Franks' is an old tribal name usually connected with Icelandic frakkr 'resolute, brave, bold' (in which $k k$ came from $n k$ by assimilation). Ramsay upholds the rival connection with the weapon name frakka (Icelandic) or franca (Old English). But the weapon so named, a throwing spear or javelin, was unknown to the Franks and the very name occurs only in English and Scandinavian; it is found neither in Franconian nor in any other Low or High German dialect. ${ }^{7}$ The etymology that Ramsay favors must therefore be rejected.

Longbeardan is the Old English form of the name of a famous Germanic tribe that settled in northern Italy. The tribal name 
appears in the latinized form Langobardi in classical antiquity. Traditionally the name is taken to mean 'long beards,' an interpretation found as early as the eighth century. Some however prefer to connect the second element -beardan with Old High German barta 'broad-ax.' On this theory the Langobards would be the men armed with long broad-axes. Evidence is wanting that this weapon was a favorite with the Langobards at any time. Indeed, we cannot say that the broad-ax was known to them at all in the early days when their name arose. The etymology thus remains speculative, and ought not to be used as a basis for any argument.

The Saxon name Old English Seaxe or Seaxan) may plausibly be connected with the obsolete word sax 'long knife, dagger, short sword,' a weapon which we know to have been used by the Saxons in warfare. It does not follow, however, that the Saxons were named after their long knives. Etymologically sax means 'tool for cutting.' It is made up of the base sag and an s-suffix. A related word is saw (Old English sagu), likewise the name of a cutting instrument. The Latin verb secäre 'cut' is also related. The tribal name may perfectly well be taken to have the etymological sense 'cutters, men noted for their skill at cutting,' or the like. Whether they were famous for woodcutting or for some other kind of cutting we have no way of knowing. The earliest known seats of the Saxons were in Holstein, a heavily wooded region, and woodcutting must have been an important activity among them. But their name may have arisen in various other ways, of course.

Our survey of Ramsay's parallels has made it clear that these give no firm support (if indeed they give any support at all) to the etymology of Scylding. The etymology itself is inherently implausible, for the reason already given. We had better take Scylding at its face value, and explain it as a patronymic in origin, derived from the personal name $S c y l d$.

\section{NOTES}

${ }^{1}$ Names I (1953), 274-276.

${ }^{2}$ Names I, 27.

${ }^{3}$ Names I, 153-162.

${ }^{4}$ See the Oxford History of England I (1936), 380 , note 3.

5 See Widsith, line 35: Offa weold Ongle 'Offa ruled Angeln.'

${ }^{\circ}$ See A. Noreen, in Namn och Bygd VIII, 6.

${ }^{7}$ See R. W. Chambers, Widsith, pp. 195-196. 